\title{
EDUCATION AS A STRATEGIC GOAL IN THE CROATIAN NON-PROFIT SECTOR AFTER COMMUNISM AND THE WAR
}

(Received: 19 September 2007; accepted: 13 February 2008)

\begin{abstract}
In the past fifteen years considerable efforts have been made in Croatian society to increase the quality of leadership in both the non-profit as well as the profit sector. In the non-profit sector education and training have been realised for leaders in non-governmental, faith and charity organisations as well as in public, educational and social care institutions. As well as many informal additional forms of education (improvement, advanced training, work on oneself) much education has been provided by non-profit organisations, for example the Open Society. Croatia defines education as a strategic goal. Inside the educational system research and experience show the importance of management and leadership in educational institutions as well as in the social care system. We are of the opinion that lack of knowledge and skills adds up to poverty. It makes sense that increasing the quality of leadership in the educational system should be one of the first strategic points for development. An improvement in the quality of management is dependent on the efficiency and the effectiveness of the educational system. Caritas Croatia, through a new mission in cooperation and partnership with Caritas Germany, Deutscher Caritasverband and the German government, has established a formal educational system for leadership in non-profit organisations through postgraduate study: Management for Non-profit Organisations and Social Advocacy. Education is a part of the non-profit sector described in diagrams. Education basically rests on non-profit governmental institutions (institutions for education, schools), but educational suppliers are both profit and non-profit organisations. Research was conducted in order to find the answers to omit open questions about leaders' educational needs and the key of quality in the educational system as well as in the whole non-profit sector.
\end{abstract}

Keywords: non-profit, non-governmental, public sector, civil society, educational institutions, social care institutions, education, quality, educational researches

* Željko Burcar, Management for Nonprofit Organisation and Social Advocacy, Catholic Theological Faculty, University of Zagreb, Kaptol 26, HR-10000 Zagreb, Croatia; zeljko.burcar@zg.t-com.hr. 
Bildung als strategisches Ziel im Non-profit-Sektor in Kroatien nach dem Kommunismus und dem Krieg: Die kroatische Gesellschaft hat in den vergangenen 15 Jahren beachtenswerte Anstrengungen unternommen, um die Führungsqualität sowohl im Non-profit- als auch im profitorientierten Sektor zu verbessern. Im Non-profit-Sektor entstanden Bildungs- und Ausbildungsgänge für die Leiter sowohl von kirchlichen und wohltätigen Nicht-Regierungs-Organisationen als auch von öffentlichen Bildungs- und Sozialeinrichtungen. Diese wurden - wie viele andere informelle Weiterbildungsangebote auch - von Non-profit-Organisationen durchgeführt wie z.B. der „Offenen Gesellschaft“. Kroatien hat Bildung zum strategischen Ziel erklärt. Im Bildungswesen zeigen Forschungsergebnisse und Erfahrung die Bedeutung von Leitung und Administration sowohl in Erziehungsinstitutionen als auch im Fürsorgewesen. Auch wir waren der Ansicht, dass das Fehlen von Wissen und mangelnde Ausbildung zur Verelendung führen. Es ist daher vernünftig, eine verbesserte Führungsqualität im Bildungswesen zum strategischen Ziel der Entwicklung zu erklären. Zusammen mit einer verbesserten Führungsqualität hängt diese von der Effektivität und Wirksamkeit des Bildungswesens ab. Der Kroatische Caritasverband hat im Rahmen eines gemeinsam mit dem Deutschen Caritasverband und der deutschen Regierung ins Leben gerufenen neuen Projektes unter dem Namen „Leitung von Non-profit-Organsationen und gesellschaftlichen Interessenvertretungen“ eine formale Ausbildung für die Leitung von Non-profit-Organisationen geschaffen. Bildung ist in Kroatien ein strategisches Ziel. Bildung ist Teil des Non-profit-Sektors, was in Diagrammen dargestellt wird. Bildung geschieht zwar vorrangig innerhalb nicht profitorientierter staatlicher Institutionen (Bildungseinrichtungen und Schulen), doch wird Bildung von profitorientierten und nicht profitorientierten Organisationen gleichermaßen angeboten. Es wurden Forscher beauftragt, die nach einer Antwort auf die Frage nach den Bildungsbedürfnissen von Leitern suchen und den Schlüssel zu einer verbesserten Qualität sowohl im Bildungswesen als auch im Non-profit-Sektor finden sollen.

Schlüsselbegriffe: Non-profit, Nicht-Regierungsebene, öffentlicher Sektor, Zivilgesellschaft, Bildungsinstitutionen, soziale Fürsorgeeinrichtungen, Bildung, Qualität, Bildungsforschung

\section{Introduction}

Croatia's newly achieved independence and separation from Yugoslavia led to positive trends which occurred in the development of society as a whole, including civil society, non-governmental sectors and non-profit organisations. Change began with the struggle for independence, and continued through the international recognition of Croatia and the positioning of the Republic of Croatia inside the European Community. It appears that the plan, organisation and implementation of independence became possible only with the charismatic leadership of the first Croatian president. The nation had a clear common aim, a common vision; it could identify itself with the defined tasks which would lead to this common aim, an independent Republic of Croatia. Now, the visions have changed, and the aims are being redefined. The Republic of Croatia is trying to establish a market-oriented economy, which means a transition in the system as a whole, the economy, and labour on the one hand and concern for the human individual on the other hand. At the same time as the creation of Croatia, large systemic changes began: in non-profit governmental institutions, in labour, in educa- 
tion, the sciences, social care and health care. By the end of the war in Croatia, the non-profit sector emerged and started to develop as a new need and as a result of the release of the human spirit.

\section{The Croatian non-profit sector}

It is defined by the fact that it does not generate profits. Thus, it includes the system of government administration, as well as non-governmental organisations, institutions, faith and charitable organisations as shown in Figure 1 below. This paper will deal with non-governmental, faith and charity organisations, as well as with institutions, especially with educational institutions. Civil society is observable through non-governmental, faith and charity organisations.

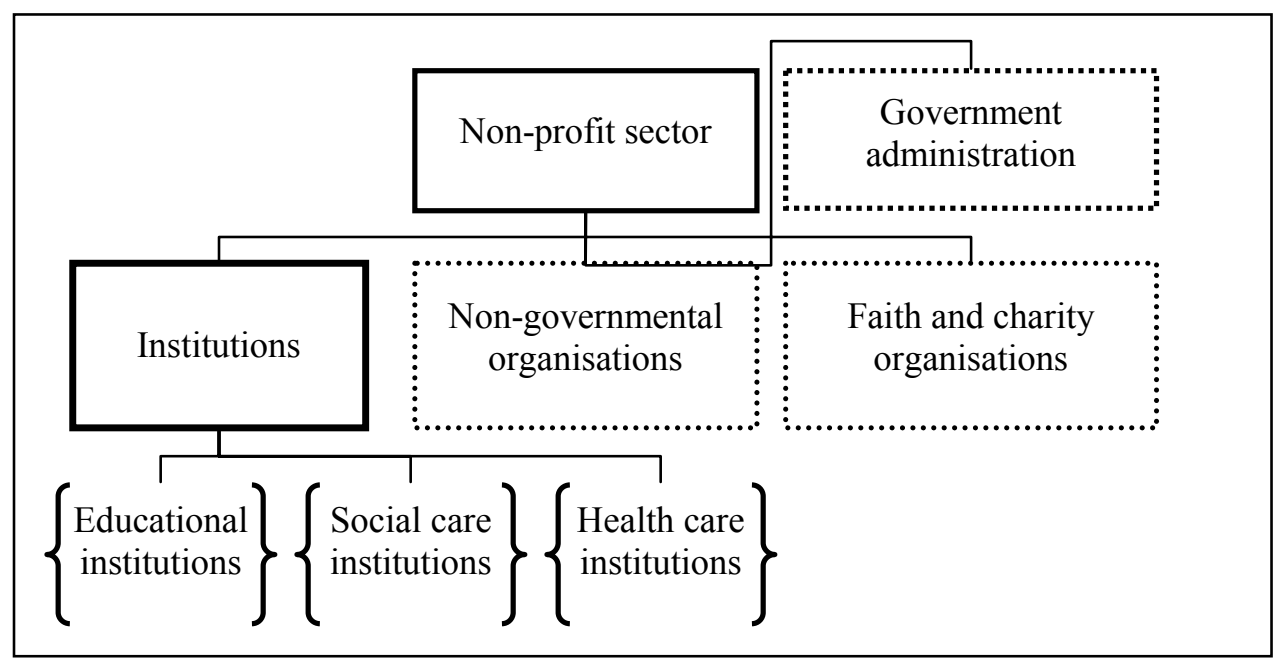

Figure 1

The Croatian non-profit sector

In accordance with the above organisational chart definite sectors can be defined:

Non-governmental organisations

Faith and charity organisations

Educational institutions

Social welfare institutions

Health care Institutions

Government administration is not the topic of this work. 


\subsection{Non-governmental organisations}

Quality management in Croatia's increasing non-profit sector is crucial. As Croatia's accession to the European Union approaches, the number of citizens' associations as non-profit and non-governmental organisations is increasing. At the same time, we are witnessing many citizens' associations being closed because of lack of membership interest, mostly caused by weak management. The process of development of the nonprofit sector is encouraged in different ways. Information is more available because of the Internet. The general public can educate itself, thus developing an understanding of the importance of uniting all over the world. Recent years have seen the expansion of international education in and for the system of institutions (educational, social care). In this way employees have been educated in a better understanding of teamwork, strength of unity and a common voice on the public stage. Although these three reasons are of considerable importance, it seems that simplifying legal procedures of registering associations is one of the most important factors in increasing the number of associations as well as for organised groups of citizens. The legal formal procedure makes it possible for citizens' associations to be created with three founding members as a minimum. With the increase of the number of non-profit and non-governmental associations, the influence of the civil sector in society is enhanced. According to the most recent data there are around 20,000 associations registered in Croatia. This figure fluctuates daily, however. Statistically, there are five societies for every thousand inhabitants (BATARELO \& BURCAR 2006). Although the number of associations demonstrates the strength of the civil sector, the large number in itself does not necessarily guarantee a strong civil sector. That is the reason why new knowledge about management and leadership in non-profit and non-governmental associations plays a very important role.

\subsection{Governmental organisations: Educational institutions}

Croatia defines education as a strategic goal. Inside the educational system research and experience show the importance of management and leadership knowledge and skills in educational institutions as well as in the social care system. The Educational System was decentralised to a local district level. Organisationally in the educational system there are smaller organisational subsystems. There are pre-school institutions, elementary school institutions, grammar schools and occupational schools, university systems and science systems. All these institutions have organisational charts (Figures 2 and 3) and principals.

Basically we can conclude that formal education relies on the educational institution. We can also agree that lack of knowledge and skills adds up to poverty. It makes sense that increasing quality of leadership in the educational system should be one of the first strategic points for development. In accordance with an increase in management quality, this depends on the efficiency and the effectiveness of the educational system. Through the educational system new managers and leaders will be educated 
and trained. Basically non-profit governmental institutions can be organised in both a centralised and decentralised fashion.

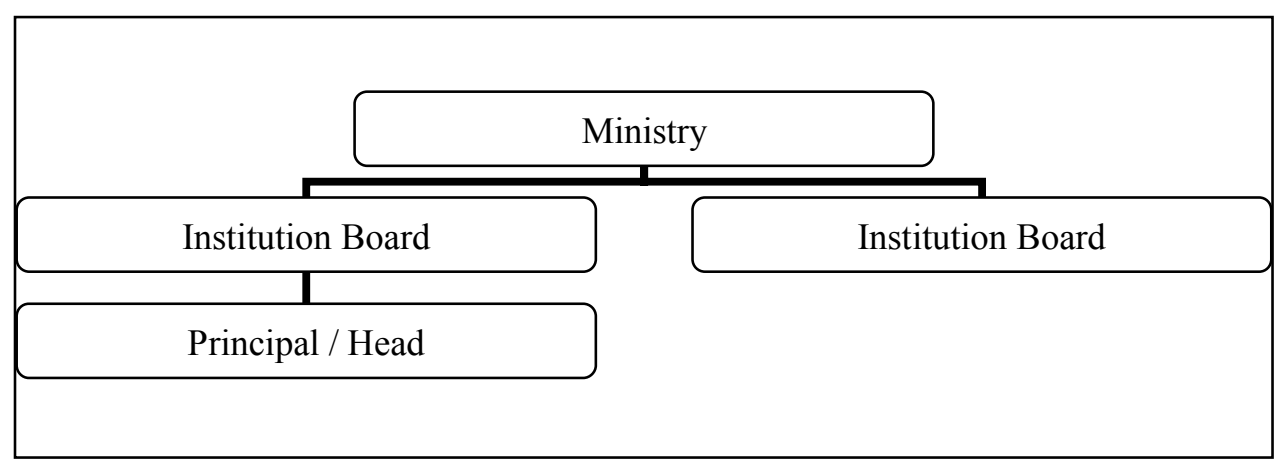

Figure 2

Structure of non-profit governmental institutions - centralised

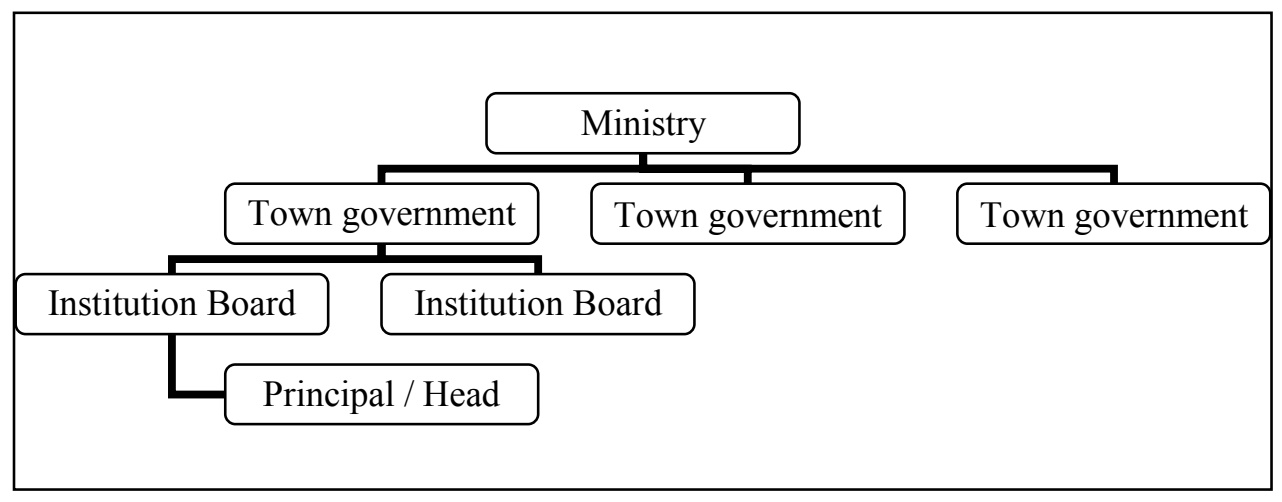

Figure 3

Structure of non-profit governmental institutions - decentralised

\section{After the war; new power in the future}

\subsection{Non-profit organisations, European trainers and support}

In 1997, the Dutch (MATRA) project started in Croatia. The basic purpose of the project was to improve the quality of leadership and management in the educational and social care system. The Project was implemented through cooperation between the Kingdom of the Netherlands and the Republic of Croatia. Approximately 100 persons from these two systems were educated for three years, including 25 school principals. The MATRA course was focused on leadership, managing and client orientation ap- 
proach. Each of the participants went through 360 hours of training and 240 hours of lecturing. Croatia has established many programs for encouraging non-profit associations, for example the work of the Open Society Institute. In turn, non-profit organisations have established non-formal and informal educational programs through their network.

\subsection{Faith and charity organisations - Caritas Croatia}

During the war, Caritas Croatia through its network played a leading role to help poor citizens with food, clothes and necessary goods. Caritas Croatia collected and distributed supplies acquired from domestic and foreign sources. After the war, helping the poor was one of their roles but not the only one. They instituted new developmental programs, for example: 'Building the Existence' as well as 'Postgraduate study: Management for Non-profit Organisations and Social Advocacy'. 'Building the Existence' was based on supporting people build their own businesses; and to help them acquire new knowledge and skills to be proud to work.

In 2003, for the first time in Croatia, and in fact in Eastern Europe, Caritas Croatia established a 'Postgraduate study: Management for Non-profit Organisations and Social Advocacy'. The Project started and was implemented with the cooperation and with considerable financial support from the German government through Deutscher Caritasverband. Postgraduate study was implemented in the Croatian higher educational system in the Catholic Faculty of Theology at the University of Zagreb. The course had the vision: through the enhancement of knowledge, skills and the use of modern management techniques for leaders in the non-profit sector to facilitate an increase in the quality of managing non-profit organisations and to bring about the creation of a positive climate for social change in Croatia. Its assignment is the mission:

- To disseminate new knowledge and expand the level of existing knowledge in the sphere of management and social advocacy.

- To enhance the development of skills in management and leadership.

- To offer management knowledge and skills with the aim of managing processes, organisational development and human resources.

- To develop the knowledge and skills for strategic planning, operative planning, managing and implementing projects, budgeting, public relations and marketing.

- To give an insight into the functioning of civil society in Croatia and the potential strength of the non-profit sector in social advocacy.

The target group are people who manage and lead in the non-profit sector, which includes organisations and institutions, from the NGO's and government sectors. The 'clients' are potential and current leaders in the non-profit sector (BATARELO \& BURCAR 2006). 


\section{Research into the educational situation and client needs in the area of leadership}

With the purpose of educational system development, much research has been provided to produce snapshot of the system. Two studies will be presented.

Educational needs of current and potential leaders in non-profit sectors (BURCAR 2006) were the focus of the first study. Through the constructed questionnaire (56 items) opinions and attitudes were examined. An intentional sample of examinees $(\mathrm{N}=24)$ that represents $65 \%$ of students on postgraduate non-profit management study experienced in additional education, estimated how offered contents of professional additional education mainly satisfied the quality. They were better satisfied with the quality of additional education outside their working collective. Offered professional additional education had been equally represented in the line of profession, planning, communication skills, guiding, leading and management. They felt a lack of additional education in the field of evaluation. The estimated sample of examinees considered that lecturers had been well prepared. They preferred lecturers outside their working environment. Additional education had been organised in plenary, as lectures in smaller groups, and also as workshops. On the basis of the results we were able to conclude that the need for better channels of information about additional education exists. Administration readily ensured replacements for employees and organisational conditions as well as the financing for the employees for additional education. Motivation of the mentioned group of examinees appeared high because of being in the company of their colleagues and thus exchanging experience, and also because of understanding how additional education can help them in their work and their practice. Reasons for absenteeism are different; especially questionable are the control and lack of encouragement in the working environment, but certainly not due to the unsatisfactory lecturer. Examinees in all working environments had access to computers and the Internet, and they received working materials during their additional education. It is undoubted that $100 \%$ of these examinees wanted to increase the quality of their education. Examinees wanted to have an influence on the choice of contents. They preferred workshops as a methodical and organisational shape of work, and equally wanted additional education from these lines of work, planning, evaluation, communication skills, leadership and management.

The second study on which factors increase quality in elementary school (BURCAR 2007) has been focused on the managing and leading in the schools. Managing and leading are crucial elements for success in the non-profit sector. Leadership and management are two distinctive and complementary systems of action. Each has its own specific activities. Both are necessary for success in today's business environment (KOTTER 1998).

Ahead of formal education we can find the educational system. The role of the educational system is to offer services for increasing knowledge and skills in the profit-sector as well as in the non-profit sector. In order to enable this, it is necessary to primarily improve the quality of management and leading inside the educational system. Therefore, in this study we will try to establish the influence of the subjects of 
systems on the quality of the systems on the one hand, and evaluations of the function and the work of the headteacher and the boards on the other. We will estimate a criteria selection for the headteachers and competences which the headteachers need to possess.

Through the constructed questionnaire (17 items) opinions and attitudes were examined. A representative sample of examinees $(\mathrm{N}=89$ headmasters in elementary schools) estimated how offered contents of professional additional education mainly satisfied the quality (they make up $10 \%$ of the population; they are representative for the population, because they are examined on the additional educational course, they are experienced and very knowledgeable). Basic statistics were used. The KolmogorovSmirnov test for normality shows that the results are distributed as Gaus distributions.

It seems that principals think the quality of the school does depend on their leadership, but much more on the teachers than on their work. The quality of the school does not depend very much on board work. It is obvious that the quality of the school depends on the teaching methods and the teachers' work and the resources available. They mainly disagree that any excellent teacher can be an excellent principal. They agree that their job is professional, and the board job is not so professional. They mainly disagree that headteachers are selected with professional criteria and owing to their professional competence. This can be explained by the fact that the law prescribes only two criteria for election, 5-year service in the profession and the possibility to be employed as a teacher. It seems that heads do not see themselves as the most responsible for the quality in the school. Probably because they do not feel that they have the tools for the selection, development, motivating, supporting, rewarding or firing of the staff. The principals estimate that differences between the teachers and the principal's scope of work exist, but in daily practice it is observed that almost $100 \%$ teachers from their own schools are chosen, regardless of the competence of other candidates that come from other schools.

Pearson's correlation moment shows that a negative significant correlation is present between years working as a principal on one hand and the following variables: the quality of the school depends on board work, a board job is a professional job, job application requirements for the headteacher require professional competences, and headteachers are chosen on the basis of professional competences, and are chosen on the basis of precise criteria. It seems that more experienced principals estimate that the boards' influence, professionalism and the election of the headteacher are based on competences and criteria which are different to the selection of less experienced principals.

Through the research about attitudes and opinions about quality and their factors it seems that the most important factors of quality in schools are teachers and their teaching methods. The heads perceive the board as a team which does not have a big impact on quality. The fact is that in accordance with today's legislation, boards elect headteachers. 


\section{Conclusions}

In the past 15 years Croatia has gone through a transitional period. Many systems change and efficiency increases. Numerous changes have been made since the declaration of independence, through the war and the liberation to the new mission and 'boarding the train' to the European Union. Leadership is changing, from the top to the bottom of the pyramid. It started with the charismatic leadership of the first Croatian president during the war and continued with new leaders. An attempt is being made to establish a systematic approach to education for current and future leaders because a large amount of research shows that leaders are the most responsible people for development. Experience from high-quality practice of Europe and Croatia is permanently implemented in the system. Research produces new knowledge about the situation and is needed as a marker for future planning, as a marker for future development.

\section{References}

BAtARelo, J.V. \& Ž. BuRCAR (2006) 'Leadership for Community: The Croatian Situation after Communism and War', Papers from Leadership Conference, Dublin 7, 36-48.

BURCAR, Ž. (2006) 'Stavovi visokoobrazovanih kadrova o stručnom usavršavanju', Andragoški glasnik 16, 41-46.

BURCAR, Ž. (2007) 'Utjecaj nekih elemenata sustava i nekih procesa na kvalitetu u osnovnoj školi’, Andragoški glasnik 18, 23-30.

KOTteR, J.P. (1998) ‘What Leaders Really Do', Harvard Business Review 37, 103-11. 